\title{
Nutrients and non-nutrients composition and bioactivity of wild and cultivated Coprinus comatus (O.F.Müll.) Pers.
}

Dejan Stojković ${ }^{\mathrm{a}, 1}$, Filipa S. Reis ${ }^{\mathrm{b}, 1}$, Lillian Barros ${ }^{\mathrm{b}}, \mathrm{Jasmina}$ Glamočlija ${ }^{\mathrm{a}}$, Ana Ćirić ${ }^{\mathrm{a}}$, Leo J.I.D. van Griensven ${ }^{c}$, Marina Sokovic ${ }^{a}{ }^{\text {, }}$, Isabel C.F.R. Ferreira ${ }^{b^{*}}$

${ }^{a}$ University of Belgrade, Department of Plant Physiology, Institute for Biological Research "Siniša Stanković”, Bulevar Despota Stefana 142, 11000 Belgrade, Serbia.

${ }^{\mathrm{b}}$ Mountain Research Center(CIMO), ESA, Polytechnic Institute of Bragança, Campus de Santa Apolónia, Ap. 1172, 5301-855 Bragança, Portugal.

${ }^{c}$ Plant Research International, Wageningen University and Research, P.O. Box 16, 6700 AA Wageningen, The Netherlands.

${ }^{1}$ These authors equally contributed to this work.

* Authors to whom correspondence should be addressed (Isabel C.F.R. Ferreira; e-mail: iferreira@ipb.pt; telephone +351-273-303219; fax +351-273-325405 and Marina D. Soković; e-mail: mris@ibiss.bg.ac.rs; telephone +381-11-2078419; fax +381-112761433). 


\begin{abstract}
Mushrooms have been reported as sources of biomolecules with various potential. Coprinus comatus was studied to obtain information about this species, comparing cultivated and wild samples. Free sugars, fatty acids, tocopherols, organic acids and phenolic acids were analysed by chromatographic techniques coupled to different detectors. C. comatus methanolic extractwas tested for its antioxidant potential (reducing power, radical scavenging activity and lipid peroxidation inhibition) and antimicrobial properties (tested towards Gram positive and negative bacteria, and microfungi). The toxicity for liver cells was tested in porcine liver primary cells. Both studied samples revealed similar nutritional value and energy contribution. The cultivated sample revealed the highest content in free sugars, monounsaturated fatty acids and tocopherols, while the wild mushroom was richer in saturated and polyunsaturated fatty acids, organic acids and phenolic compounds. The cultivated species also revealed the highest antioxidant potential and antimicrobial activity (with exception towards Gram negative bacteria and Aspergillus ochraceus). Both species revealed no toxicity towards porcine liver cells. The present study proved that cultivated and wild mushrooms from the same species could be excellent options as food and as sources of nutritional and bioactive compounds. Furthermore, differences in wild and cultivated samples were comparatively investigated for the first time.
\end{abstract}

Keywords: Coprinus comatus; Edible mushroom; Nutrients/Non-nutrients; Antioxidant activity; Antimicrobial activity.

\title{
1. Introduction
}


Mushrooms and their components have been reported as having numerous positive health benefits, mainly on the basis of in vitro and in vivo animal trials (anti-cancer, immune-modulation, cardiovascular diseases, etc.). However, the majority of these effects are indirect since they are due to a stimulation or modulation of natural cellular immunity (Roupas et al., 2012). Therefore, with an equilibrated diet associated with the consumption of mushrooms, we can take advantage of the organoleptic/nutritional properties of edible mushrooms (Kalač, 2009) and their possible therapeutic properties, due to antioxidant, antitumor and antimicrobial activity (Ferreira et al., 2009 and 2010; Alves et al., 2012).

Coprinus comatus (O.F.Müll.) Pers., also known as shaggy ink cap, lawyer's wig or shaggy mane, is an edible mushroom species commonly found all over the world; moreover, it is also cultivated in many countries (Li et al., 2010). There are a few studies concerning chemical characterization of $C$. comatus in an attempt to qualify this species as a dietary option. Portuguese wild samples were characterized for their nutritional value, sugars composition, fatty acids profile, tocopherols and ascorbic acid contents (Vaz et al., 2011). Wild samples from Turkey were also studied for their fatty acids profile (Yilmaz et al., 2006) and also studies describing the flavour compounds from C. comatus have been described before (Dijkstra and Wikén, 1976).

Several bioactive functions have been attributed to this species along the time, both in cultivated and wild samples, such as hypoglycemic (Bailey et al., 1984), immunomodulatory and antitumor (Jiang et al., 2013) or antioxidant potential (Tsai et al., 2009; Li et al., 2010; Vaz et al, 2011). Mycelia extracts of $C$. comatus have been also studied revealing antioxidant potential (Tsai et al., 2009) and some extracts proved to interfere with androgen receptor function in LNCaP prostate cancer cells (Zaidman et al., 2008). The hypoglycemic effect, as also the improvement of glucose tolerance, was 
still presented by C. comatus mycelium (Ding et al., 2010) and by some polysaccharides extracted from selenium-enriched mycelia (Yu et al., 2009). Moreover, these polysaccharides, tested in diabetic mice, revealed hypolipidemic effects and antioxidant properties, suggesting that their antioxidant activity could be directly or indirectly responsible for its hypoglycemic and hypolipidemic properties (Yu et al., 2009).

In our continuing search for biologically active substances from mushroom species $C$. comatus was chosen for the analysis in order to evaluate differences in chemical composition and bioactivity between wild and one of the most widely cultivated species. In the present study, the chemical characterization of $C$. comatus was achieved through the evaluation of nutrients (energetic value, free sugars, fatty acids and tocopherols) and non-nutrients (organic acids and phenolic acids); the bioactivity of its methanolic extract was evaluated in terms of antioxidant and antimicrobial potential, as was the confirmation of non-toxicity tested in a primary cell culture from porcine liver designed as PLP2. All the assays were performed in order to compare cultivated and wild samples.

\section{Material and Methods}

\subsection{Sampling of mushroom species}

Cultivated fruiting bodies of Coprinus comatus (O.F.Müll.) Pers (strain: S 435) were obtained from the Mushroom Experimental Station (Horst, The Netherlands). The studied samples from Serbia were wild species collected in the Lipovica Forest, near Belgrade, in October, 2012. A voucher specimen has been deposited at the Fungal Collection Unit of the Mycological Laboratory, Department for Plant Physiology, Institute for Biological Research "Siniša Stanković”, Belgrade, Serbia, under number Cc-LFds-2012. 
All the samples were lyophilized, reduced to a fine dried powder (20 mesh), mixed to obtain homogenous samples and stored in a desiccator, protected from light, until further analysis.

\subsection{Standards and Reagents}

Acetonitrile $99.9 \%, n$-hexane $95 \%$ and ethyl acetate $99.8 \%$ were of HPLC grade from Fisher Scientific (Lisbon, Portugal). The fatty acids methyl ester (FAME) reference standard mixture 37 (standard 47885-U) was purchased from Sigma (St. Louis, MO, USA), as also other individual fatty acid isomers, trolox (6-hydroxy-2,5,7,8tetramethylchroman-2-carboxylic acid), sugar, tocopherol, organic acid and phenolic compound standards. Racemic tocol, $50 \mathrm{mg} / \mathrm{mL}$, was purchased from Matreya (PA, USA). 2,2-Diphenyl-1-picrylhydrazyl (DPPH) was obtained from Alfa Aesar (Ward Hill, MA, USA). Dimethylsulfoxide (DMSO) (Merck KGaA, Germany) was used as a solvent in antimicrobial assays. Fetal bovine serum (FBS), Hank's balanced salt solution, nonessential amino acids solution $(2 \mathrm{mM})$, penicillin/streptomycin solution (100 U/mL and $100 \mu \mathrm{g} / \mathrm{mL}$, respectively), DMEM medium was from Hyclone (Logan, USA). Acetic acid, ellipticine and sulforhodamine B (SRB) were from Sigma Chemical Co. (Saint Louis, USA). Methanol and all other chemicals were of analytical grade and purchased from common sources. Water was treated in a Milli-Q water purification system (TGI Pure Water Systems, USA).

\subsection{Nutrients composition of C. comatus fruiting bodies}

2.3.1. Nutritional value. The samples were analysed for the chemical composition (moisture, proteins, fat, carbohydrates and ash) using the standard procedures (AOAC, 1995). The crude protein content $(\mathrm{N} \times 4.38)$ of the samples was estimated by the macro- 
Kjeldahl method; the crude fat was determined by extracting a known weight of powdered sample with petroleum ether, using a Soxhlet apparatus; the ash content was determined by incineration at $600 \pm 15^{\circ} \mathrm{C}$. Total carbohydrates were calculated by difference. Energy was calculated according to the following equation: Energy $(\mathrm{kcal})=$ $4 \times(\mathrm{g}$ protein $+\mathrm{g}$ carbohydrate $)+9 \times(\mathrm{g}$ fat $)$.

2.3.2. Free sugars. Free sugars were determined by a high performance liquid chromatograph (HPLC) system consisted of an integrated system with a pump (Knauer, Smartline system1000), degasser system(Smartlinemanager5000) and an auto-sampler (AS-2057 Jasco), coupled to a refraction index detector (RI detector Knauer Smartline 2300) as previously described by the authors Reis et al. (2012a). Sugars identification was made by comparing the relative retention times of sample peaks with standards. Data were analyzed using Clarity 2.4 Software (DataApex).Quantification was based on the RI signal response of each standard, using the internal standard (IS, raffinose) method and by using calibration curves obtained from the commercial standards of each compound. The results were expressed in g per $100 \mathrm{~g}$ of dry weight.

2.3.3. Fatty acids. Fatty acids were determined after a transesterification procedure as described previously by the authors Reis et al. (2012a). The fatty acid profile was analyzed with a DANI 1000gas chromatographer (GC) equipped with a split/splitless injector and a flame ionization detector (FID). Fatty acid identification was made by comparing the relative retention times of FAME peaks from samples with standards. The results were recorded and processed using CSW 1.7 software (DataApex 1.7) and expressed as a weight percentage of the crude fat. 
2.3.4. Tocopherols. Tocopherols were determined following a procedure previously optimized and described by the authors Heleno et al., 2010. Analysis was performed by HPLC (equipment described above), and a fluorescence detector (FP-2020; Jasco) programmed for excitation at $290 \mathrm{~nm}$ and emission at $330 \mathrm{~nm}$. The compounds were identified by chromatographic comparisons with authentic standards. Quantification was based on the fluorescence signal response of each standard, using the IS (tocol) method and by using calibration curves obtained from commercial standards of each compound. The results were expressed in $\mu \mathrm{g}$ per100 g of dry weight.

\subsection{Non-nutrients composition of C. comatus fruiting bodies}

2.4.1. Organic acids. Organic acids were determined by ultra fast liquid chromatography (UFLC, Shimadzu 20A series) coupled with a photodiode array detector (PDA) as previously optimized and described by the authors (Barros et al., 2013).The organic acids were quantified by the comparison of the area of their peaks recorded at $215 \mathrm{~nm}$ with calibration curves obtained from commercial standards of each compound. The results were expressed in g per $100 \mathrm{~g}$ of dry weight.

2.4.2. Phenolic acids and related compounds. Phenolic acids determination was performed using the UFLC mentioned above, as previously described by Reis et al. (2012b). Detection was carried out in a photodiode array detector (PDA), using $280 \mathrm{~nm}$ as the preferred wavelength. The phenolic compounds were quantified by comparison of the area of their peaks recorded at $280 \mathrm{~nm}$ with calibration curves obtained from commercial standards of each compound. The results were expressed in mg per $100 \mathrm{~g}$ of dry weight. 


\subsection{Bioactivity of C. comatus methanolic extract}

2.5.1. Extract preparation. The lyophilized sample $(1 \mathrm{~g})$ was extracted by stirring with $40 \mathrm{~mL}$ of methanol for $1 \mathrm{~h}$ and subsequently filtered through Whatman No. 4 paper. The residue was then extracted with $20 \mathrm{~mL}$ of methanol for $1 \mathrm{~h}$. The combined methanolic extracts were evaporated at $40^{\circ} \mathrm{C}$ (rotary evaporator Büchi R-210) to dryness and redissolved in a) methanol for antioxidant activity assays (20 mg/mL), b) $5 \%$ solution of DMSO in distilled water for antimicrobial activity assays $(100 \mathrm{mg} / \mathrm{mL})$, and $c$ ) distillated water for the toxicity assay in porcine liver primary cells $(8 \mathrm{mg} / \mathrm{mL})$.

2.5.2. Antioxidant activity assays. Successive dilutions were made from the stock solution and submitted to the in vitro assays already described by Reis et al. (2012b) to evaluate the antioxidant activity of the samples. The sample concentrations $(\mathrm{mg} / \mathrm{mL})$ providing $50 \%$ of antioxidant activity or 0.5 of absorbance $\left(\mathrm{EC}_{50}\right)$ were calculated from the graphs of antioxidant activity percentages (DPPH, $\beta$-carotene/linoleate and TBARS assays) or absorbance at $690 \mathrm{~nm}$ (ferricyanide/Prussian blue assay) against sample concentrations. Trolox was used as a positive control.

Folin-Ciocalteu assay. One of the extract solutions $(5 \mathrm{mg} / \mathrm{mL} ; 1 \mathrm{~mL})$ was mixed with Folin-Ciocalteu reagent $(5 \mathrm{~mL}$, previously diluted with water $1: 10, \mathrm{v} / \mathrm{v})$ and sodium carbonate $(75 \mathrm{~g} / \mathrm{L}, 4 \mathrm{~mL})$. The tubes were vortex mixed for $15 \mathrm{~s}$ and allowed to stand for $30 \mathrm{~min}$ at $40^{\circ} \mathrm{C}$ for color development. Absorbance was then measured at $765 \mathrm{~nm}$ (Analytikjena spectrophotometer; Jena, Germany). Gallic acid was used to obtain the standard curve and the reduction of the Folin-Ciocalteu reagent by the samples was expressed as mg of gallic acid equivalents (GAE) per g of extract.

Ferricyanide/Prussian blue assay. The extract solutions with different concentrations $(0.5 \mathrm{~mL})$ were mixed with sodium phosphate buffer $(200 \mathrm{mmol} / \mathrm{L}, \mathrm{pH} 6.6,0.5 \mathrm{~mL})$ and 
potassium ferricyanide $(1 \% \mathrm{w} / \mathrm{v}, 0.5 \mathrm{~mL})$. The mixture was incubated at $50^{\circ} \mathrm{C}$ for 20 min, and trichloroacetic acid $(10 \% \mathrm{w} / \mathrm{v}, 0.5 \mathrm{~mL})$ was added. The mixture $(0.8 \mathrm{~mL})$ was poured in the 48 wells plate, the same with deionized water $(0.8 \mathrm{~mL})$ and ferric chloride $(0.1 \% \mathrm{w} / \mathrm{v}, 0.16 \mathrm{~mL})$, and the absorbance was measured at $690 \mathrm{~nm}$ in ELX800Microplate Reader (Bio-Tek Instruments, Inc; Winooski, USA).

$D P P H$ radical-scavenging activity assay. This methodology was performed using the Microplate Reader mentioned above. The reaction mixture on 96 well plate consisted of a solution by the well of the extract solutions with different concentrations ( $30 \mu \mathrm{L})$ and methanolic solution $(270 \mu \mathrm{L})$ containing DPPH radicals $\left(6 \times 10^{-5} \mathrm{~mol} / \mathrm{L}\right)$. The mixture was left to stand for $30 \mathrm{~min}$ in the dark, and the absorption was measured at $515 \mathrm{~nm}$. The radical scavenging activity (RSA) was calculated as a percentage of DPPH discoloration using the equation: $\% \mathrm{RSA}=\left[\left(\mathrm{A}_{\mathrm{DPPH}}-\mathrm{A}_{\mathrm{S}}\right) / \mathrm{A}_{\mathrm{DPPH}}\right] \times 100$, where $\mathrm{A}_{\mathrm{S}}$ is the absorbance of the solution containing the sample, and $\mathrm{A}_{\mathrm{DPPH}}$ is the absorbance of the DPPH solution.

Inhibition of $\beta$-carotene bleaching or $\beta$-carotene/linoleate assay. A solution of $\beta$ carotene was prepared by dissolving $\beta$-carotene $(2 \mathrm{mg})$ in chloroform $(10 \mathrm{~mL})$. Two milliliters of this solution were pipetted into a round-bottom flask. The chloroform was removed at $40^{\circ} \mathrm{C}$ under vacuum and linoleic acid $(40 \mathrm{mg})$, Tween 80 emulsifier (400 $\mathrm{mg})$, and distilled water $(100 \mathrm{~mL})$ were added to the flask with vigorous shaking. Aliquots $(4.8 \mathrm{~mL})$ of this emulsion were transferred into test tubes containing extract solutions with different concentrations $(0.2 \mathrm{~mL})$. The tubes were shaken and incubated at $50^{\circ} \mathrm{C}$ in a water bath. As soon as the emulsion was added to each tube, the zero time absorbance was measured at $470 \mathrm{~nm}$. $\beta$-Carotene bleaching inhibition was calculated using the following equation: (Absorbance after $2 \mathrm{~h}$ of assay/ initial absorbance) $\times 100$. 
Thiobarbituric acid reactive substances (TBARS) assay. Porcine (Sus scrofa) brains were obtained from official slaughtered animals, dissected, and homogenized with Polytron in an ice cold Tris- $\mathrm{HCl}$ buffer $(20 \mathrm{mM}, \mathrm{pH} 7.4)$ to produce a $1: 2 \mathrm{w} / \mathrm{v}$ brain tissue homogenate which was centrifuged at $3000 \mathrm{~g}$ for10 min. An aliquot $(100 \mu \mathrm{L})$ of the supernatant was incubated with the different concentrations of the sample solutions $(200 \mu \mathrm{L})$ in the presence of $\mathrm{FeSO}_{4}(10 \mathrm{mM} ; 100 \mu \mathrm{L})$ and ascorbic acid $(0.1 \mathrm{mM} ; 100$ $\mu \mathrm{L})$ at $37{ }^{\circ} \mathrm{C}$ for $1 \mathrm{~h}$. The reaction was stopped by the addition of trichloroacetic acid $(28 \% \mathrm{w} / \mathrm{v}, 500 \mu \mathrm{L})$, followed by thiobarbituric acid (TBA, 2\%, w/v, $380 \mu \mathrm{L})$, and the mixture was then heated at $80^{\circ} \mathrm{C}$ for $20 \mathrm{~min}$. After centrifugation at $3000 \mathrm{~g}$ for $10 \mathrm{~min}$ to remove the precipitated protein, the color intensity of the malondialdehyde (MDA)TBA complex in the supernatant was measured by its absorbance at $532 \mathrm{~nm}$. The inhibition ratio (\%) was calculated using the following formula: Inhibition ratio $(\%)=[(\mathrm{A}-\mathrm{B}) / \mathrm{A}] \times 100 \%$, where $\mathrm{A}$ and $\mathrm{B}$ were the absorbance of the control and the sample solution, respectively.

2.5.3. Antibacterial activity assays. The following Gram-negative bacteria: Escherichia coli (ATCC 35210), Pseudomonas aeruginosa (ATCC 27853), Salmonella typhimurium (ATCC 13311), Enterobacter cloacae (ATCC 35030), and Gram-positive bacteria: Staphylococcus aureus (ATCC 6538), Bacillus cereus (clinical isolate), Micrococcus flavus (ATCC 10240), and Listeria monocytogenes (NCTC 7973) were used. The microorganisms were obtained from the Mycological laboratory, Department of Plant Physiology, Institute for biological research "Siniša Stanković", University of Belgrade, Serbia.

The minimum inhibitory (MIC) and minimum bactericidal (MBC) concentrations were determined by the microdilution method (Espinel-Ingroff, 2001). Fresh overnight 
culture of bacteria was adjusted by the spectrophotometer to a concentration of $1 \times 10^{5}$ $\mathrm{CFU} / \mathrm{mL}$. The requested $\mathrm{CFU} / \mathrm{mL}$ corresponded to a bacterial suspension determined in a spectrophotometer at $625 \mathrm{~nm}$ (OD625). Dilutions of inocula were cultured on solid medium to verify the absence of contamination and check the validity of the inoculum. Different solvent dilutions of methanolic extract were carried out over the wells containing $100 \mu \mathrm{L}$ of Tryptic Soy Broth (TSB) and afterwards, $10 \mu \mathrm{L}$ of inoculum was added to all the wells. The microplates were incubated for $24 \mathrm{~h}$ at $37^{\circ} \mathrm{C}$. The MIC of the samples was detected following the addition of $40 \mu \mathrm{L}$ of iodonitrotetrazolium chloride (INT) $(0.2 \mathrm{mg} / \mathrm{mL})$ and incubation at $37^{\circ} \mathrm{C}$ for $30 \mathrm{~min}$. The lowest concentration that produced a significant inhibition (around 50\%) of the growth of the bacteria in comparison with the positive control was identified as the MIC. The minimum inhibitory concentrations (MICs) obtained from the susceptibility testing of various bacteria to tested extracts were determined also by a colorimetric microbial viability assay based on reduction of a INT color and compared with positive control for each bacterial strains (CSLI, 2006; Tsukatani et al., 2012). MBC was determined by serial sub-cultivation of $10 \mu \mathrm{L}$ into microplates containing $100 \mu \mathrm{L}$ of TSB. The lowest concentration that shows no growth after this sub-culturing was read as the MBC. Standard drugs, namely streptomycin and ampicillin were used as positive controls. 5\% DMSO was used as negative control.

2.5.4. Antifungal activity assays. For the antifungal bioassays, the following microfungi were used: Aspergillus fumigatus (1022), Aspergillus ochraceus (ATCC 12066), Aspergillus versicolor (ATCC 11730), Aspergillus niger (ATCC 6275), Trichoderma viride (IAM 5061), Penicillium funiculosum (ATCC 36839), Penicillium ochrochloron (ATCC 9112) and Penicillium verrucosum var. cyclopium (food isolate). The organisms 
were obtained from the Mycological Laboratory, Department of Plant Physiology, Institute for Biological Research "Siniša Stanković", Belgrade, Serbia. The micromycetes were maintained on malt agar (MA) and the cultures were stored at $4^{\circ} \mathrm{C}$ and sub-cultured once a month (Booth, 1971).

The fungal spores were washed from the surface of agar plates with sterile $0.85 \%$ saline containing $0.1 \%$ Tween $80(\mathrm{v} / \mathrm{v})$. The spore suspension was adjusted with sterile saline to a concentration of approximately $1.0 \times 10^{5}$ in a final volume of $100 \mu \mathrm{L} /$ well. The inocula were stored at $4{ }^{\circ} \mathrm{Cfor}$ further use. Dilutions of the inocula were cultured on solid MA to verify the absence of contamination and to check the validity of the inoculum.

Minimum inhibitory concentrations (MICs) determination was performed by a serial dilution technique using96-well microtitre plates. The investigated extract was dissolved in $5 \%$ solution of DMSO and added to broth malt medium with fungal inoculum. The microplates were incubated for $72 \mathrm{~h}$ at $28^{\circ} \mathrm{C}$. The lowest concentrations without visible growth (at the binocular microscope) were defined as MIC. The minimum fungicidal concentrations (MFCs) were determined by serial subcultivation of $2 \mu \mathrm{L}$ in microtitre plates containing $100 \mu \mathrm{L}$ of malt broth per well and further incubation for $72 \mathrm{~h}$ at $28^{\circ} \mathrm{C}$. The lowest concentration with no visible growth was defined as the MFC, indicating 99.5\% killing of the original inoculum. $5 \%$ DMSO was used as a negative control, while bionazole and ketokonazole were used as positive controls.

2.5.5. Toxicity for liver cells assay. A cell culture was prepared from a freshly harvested porcine liver obtained from a local slaughter house. It was designed as PLP2. Briefly, the liver tissues were rinsed in Hank's balanced salt solution containing $100 \mathrm{U} / \mathrm{mL}$ 
penicillin and $100 \mu \mathrm{g} / \mathrm{mL}$ streptomycin and divided into $1 \times 1 \mathrm{~mm}^{3}$ explants. Some of these explants were placed in $25 \mathrm{~cm}^{2}$ tissue flasks in DMEM supplemented with $10 \%$ fetal bovine serum, $2 \mathrm{mM}$ nonessential amino acids and $100 \mathrm{U} / \mathrm{mL}$ penicillin, 100 $\mathrm{mg} / \mathrm{mL}$ streptomycin and incubated at $37^{\circ} \mathrm{C}$ with a humidified atmosphere containing $5 \% \mathrm{CO}_{2}$. The medium was changed every 2 days. Cultivation of the cells was continued with direct monitoring every 2-3 days using a phase contrast microscope. Before confluence, cells were sub-cultured and plated in96-well plates at a density of $1.0 \times 10^{4}$ cells $/$ well, and cultivated in DMEM medium with $10 \% \mathrm{FBS}, 100 \mathrm{U} / \mathrm{mL}$ penicillin and $100 \mu \mathrm{g} / \mathrm{mL}$ streptomycin (Abreu et al., 2011). Cells were treated for 48hwith the different diluted sample solutions and the same procedure described in the previous section for SRB assay was followed. The results were expressed in $\mathrm{GI}_{50}$ values (sample concentration that inhibited $50 \%$ of the net cell growth). Ellipticine was used as positive control.

\subsection{Statistical analysis}

Three samples were used and all the assays were carried out in triplicate. The results are expressed as mean values and standard deviation (SD). The results were analyzed using one-way analysis of variance (ANOVA) followed by Tukey's HSD Test with $\alpha=0.05$. This analysis was carried out using SPSS v. 18.0 program.

\section{Results and discussion}

\subsection{Composition in nutrients and non-nutrients}

The composition in nutrients of $C$. comatus samples is presented in Table 1. The cultivated species revealed a higher content in fat $(1.98 \mathrm{~g} / 100 \mathrm{~g})$. The wild species showed the highest levels of proteins $(11.84 \mathrm{~g} / 100 \mathrm{~g})$. There were no significant differences concerning ash and carbohydrates content, and energetic contribution of 
both samples. It could be infer that both cultivated and wild C. comatus from different origins have a similar nutritional value. This was also confirmed by the results reported by us in a study with $C$. comatus from Portugal (energetic value $=354.27 \pm 1.18 \mathrm{kcal} / 100$ g; Vaz et al., 2011).

Regarding free sugars composition, fructose was only found in the cultivated mushroom (0.11 g/100 g; Table 1 and Figure 1A), which can be explained by the growth conditions of this sample. Since wild $C$. comatus is a saprotrophic species the absence of this sugar is normal, while in cultivated sample this monosaccharide may be obtained from the (rich) compost prepared for the mushrooms development. Another study performed by our research group with a wild sample of $C$. comatus confirmed the absence of fructose (Vaz et al., 2011). Other study demonstrated that only mycorrhizal species revealed fructose in their chemical profile (these species obtain fructose from the plant); saprotrophic species did not reveal this sugar (Grangeia et al., 2011). Mannitol and trehalose, also very common in mushrooms, were detected in both samples (1.41-8.75 g/100 g), and the cultivated mushroom revealed the higher content in total free sugars $(10.27 \mathrm{~g} / 100 \mathrm{~g})$. It was previously shown that trehalose content was high in fruiting bodies $(1.69 \mathrm{~g} / 100 \mathrm{~g})$ of C. comatus from Taiwan (Tsai, 2007).

The fatty acids quantified in higher amounts in C. comatus (Table 1; Figure 1B) were palmitic acid (C16:0), stearic acid (C18:0), oleic acid (C18:1n9) and linoleic acid (C18:2n6), being the saturated fatty acids (SFA; palmitic and stearic acids) present in lower amounts (2.09-12.88\%; Table 1). Oleic acid (monounsaturated fatty acidMUFA) was found in higher percentages in the cultivated sample (36.38\%; Table 1 and Figure 1B); linoleic acid (polyunsaturated fatty acid- PUFA) was the main fatty acid presented by both samples (50.49-64.08\%; Table 1 and Figure 1B). The cultivated sample was richer in MUFA (36.75\%) and, although the wild sample presented the 
highest levels of SFA (18.72\%), it was also the sample with the highest content in PUFA (66.01\%), the first values being much lower than the latter (Table 1). The prevalence of PUFA, mainly linoleic acid, was previously reported in wild C. comatus from Portugal (Vaz et al., 2011) and Turkey (Yilmaz et al., 2006). $\alpha$-Tocopherol isoform was only detected in the wild sample $(13.24 \mu \mathrm{g} / 100 \mathrm{~g}$; Table 1 and Figure 1C). On the other hand, $\beta$ - and $\gamma$-tocopherol were only found in the cultivated species $(375.99 \mu \mathrm{g} / 100 \mathrm{~g}$ and $165.57 \mu \mathrm{g} / 100 \mathrm{~g}$, respectively; Table 1 and Figure 1C). $\delta$-tocopherol was the only isoform found in both species (31.76 $46.67 \mu \mathrm{g} / 100 \mathrm{~g})$. As in the profile of free sugars, it was the cultivated sample that revealed the highest content of total tocopherols $(588.24 \mu \mathrm{g} / 100 \mathrm{~g})$. It should be highlighted that tocopherols, as other vitamins, are very susceptible to oxidation processes and their contents are highly variable. For example, wild C. comatus from Portugal revealed a total content in tocopherols of $301.03 \pm 26.71 \mu \mathrm{g} / 100 \mathrm{~g}$ (Vaz et al., 2011).

Regarding C. comatus organic acids profile, it was possible to quantify five different compounds (Table 2), namely oxalic, quinic, malic, citric and fumaric acids. All the compounds were detected in both samples (Figure 2A). The wild mushroom from Serbia was the one that revealed the highest concentration in all the individual organic acids (0.65-11.84 g/100 g) and, therefore, the highest content in total organic acids (20.63 g/100 g). The cultivated mushroom showed less than half the concentration in organic acids, compared to the previous one $(9.97 \mathrm{~g} / 100 \mathrm{~g})$. Concerning phenolic acids, the studied samples revealed the presence of gallic, $p$-hydroxybenzoic and $p$-coumaric acids, as also the related compound cinnamic acid (Table 2). Gallic acid was only present in the cultivated sample $(0.10 \mathrm{mg} / 100 \mathrm{~g})$ and $p$-coumaric acid was only found in the wild mushroom $(0.15 \mathrm{mg} / 100 \mathrm{~g})$ (Figure 2B). A similar profile ( $p$-hydroxybenzoic, 
$p$-coumaric and cinnamic acids) was observed in a wild sample from Portugal (Vaz et al., 2011). p-Hydroxybenzoic acid was detected in higher amounts in the wild sample (0.09 $\mathrm{mg} / 100 \mathrm{~g})$, while the related compound cinnamic acid was found in higher concentration in the cultivated mushroom $(0.10 \mathrm{mg} / 100 \mathrm{~g})$. Analyzing these results we can conclude that the wild sample was richer in phenolic acids $(0.24 \mathrm{mg} / 100 \mathrm{~g})$ comparing with the cultivated one $(0.17 \mathrm{mg} / 100 \mathrm{~g})$.

\subsection{Bioactive properties}

Analyzing the results for the antioxidant potential (Table 3), both samples (methanolic extracts) revealed similar reducing power evaluated through the Folin-Ciocalteu assay (24.61-25.98 mg GAE/g extract). The cultivated mushroom revealed a higher reducing power, when evaluated through the Ferricyanide/Prussian blue assay $\left(\mathrm{EC}_{50}=1.05\right.$ $\mathrm{mg} / \mathrm{mL}$ ), and also higher than the reducing power previously reported for Portuguese $C$. comatus $\left(\mathrm{EC}_{50}=1.47 \pm 0.01 \mathrm{mg} / \mathrm{mL}\right.$; Vaz et al., 2011). The cultivated sample also revealed the highest lipid peroxidation inhibition, since it presented the lowest $\mathrm{EC}_{50}$ values for $\beta$-carotene/linoleate and TBARS assays $(0.36 \pm 0.03$ and $1.15 \pm 0.27 \mathrm{mg} / \mathrm{mL}$, respectively). $\beta$-carotene bleaching inhibition was also higher than the one described for wild C. comatus from Portugal $\left(\mathrm{EC}_{50}=1.26 \pm 0.01 \mathrm{mg} / \mathrm{mL}\right.$; Vaz et al., 2011). The wild sample demonstrated the highest radical scavenging activity, since it presented a lower $\mathrm{EC}_{50}$ value for this assay $(3.76 \pm 0.48 \mathrm{mg} / \mathrm{mL})$. Concluding, generally, the cultivated sample revealed the highest antioxidant potential, once it demonstrated the better results for three of the five assays realized.

Methanolic extracts of cultivated and wild C. comatus samples exhibited strong antibacterial activity against all bacteria tested (Table 4). Both extracts showed highest antibacterial potential against Staphylococcus aureus (MIC-0.0625 and $1.5 \mathrm{mg} / \mathrm{mL}$; 
MBC-0.125 and $3.0 \mathrm{mg} / \mathrm{mL}$ ) and Bacillus cereus (MIC- 0.0625 and $0.75 \mathrm{mg} / \mathrm{mL}$; MBC0.125 and $3.0 \mathrm{mg} / \mathrm{mL}$ ). The lowest antibacterial activity was achieved against Escherichia coli (MIC-3.0 mg/mL; MBC- $6.0 \mathrm{mg} / \mathrm{mL}$ ). Methanolic extract of cultivated (MIC-0.0625-1.25 mg/mL; MBC-0.125-6.25 mg/mL) C. comatus sample in general showed higher antibacterial potential than extract of wild sample (MIC-0.75-3.0 $\mathrm{mg} / \mathrm{mL}$; MBC-3.0-6.25 mg/ml). Both extracts possessed the same activity against $E$. coli. Methanolic extract of wild samples showed higher inhibitory activity than extract of cultivated sample, but bactericidal activity was higher in the case of Enterobacter cloacae. $\mathrm{MeOH}$ extract of wild sample showed higher activity than extract of cultivated sample only against Salmonella typhimurium. In the cases of Staphylococcus aureus and Bacillus cereus, both extracts possessed higher activity than the commercial antibiotics streptomycin and ampicillin. Regarding the antifungal activity (Table 5), the highest fungicidal potential was verified for Trichoderma viride (MIC- 0.25-1.5 $\mathrm{mg} / \mathrm{mL}$; MFC- $1.5-3.0 \mathrm{mg} / \mathrm{mL}$ ) and Aspergillus versicolor (MIC- 0.2-0.75 mg/mL; MFC- $1.5-3.0 \mathrm{mg} / \mathrm{mL})$. The lowest antifungal activity was achieved towards Aspergillus fumgiatus and Penicillium verrucosum var cyclopium (MIC- 3.0 and MFC- 6.25 $\mathrm{mg} / \mathrm{mL}$ ) for both extracts. Methanolic extract of wild sample of $C$. comatus showed the lowest activity against Aspergillus niger (MIC- $3.0 \mathrm{mg} / \mathrm{mL}$ and MFC $12.5 \mathrm{mg} / \mathrm{mL}$ ). In general the cultivated sample showed higher antifungal activity with exception of Aspergillus fumgiatus and Penicillium verrucosum var cyclopium where both extracts showed the same activity, and in the case of Aspergillus versicolor where the extract of wild sample exhibited higher fungicidal effect. Comparing the antifungal activity of bifonazole and ketoconazole to the investigated extracts, both extracts were more efficient against Penicillium ochrochloron than ketoconazole. 
Ehssan and Saadabi (2012) showed that the ethanolic extract of C. comatus from Sudan was active against all of the tested microorganisms except Aspergillus niger, Proteus vulgaris and Pseudomonas aeruginosa, tested by disc-diffusion method. Petroleum ether extracts were active against Escherichia coli. The minimum inhibitory concentrations (MICs) of the most active extracts were determined against reference organisms (Staphylococcus aureus, Escherichia coli, Proteus vulgaris, Pseudomonas aeruginosa, Candida albicans and Aspergillus niger); MICs ranged between 2.5 and 5 $\mathrm{mg} / \mathrm{mL}$. To our knowledge, for some mushroom species, like it is C. comatus, there are no more available data about antimicrobial activity of fruiting body.

As the methanolic extracts gave antioxidant and antimicrobial activity, it was important to guarantee that the extract is only toxic for microorganisms but not for other cells. In this way, the extract could be used in humans for health purposes. Liver cells are considered the best in vitro model for studies of human cytotoxicity. The studied samples revealed no toxicity in liver primary culture PLP2, once the $\mathrm{GI}_{50}$ values obtained were higher than the highest concentration tested $(>400 \mu \mathrm{g} / \mathrm{mL})$. The positive control ellipticine gave a $\mathrm{GI}_{50}=2.06 \pm 0.03 \mu \mathrm{g} / \mathrm{mL}$ (Table 6).

\section{Conclusions}

The cultivated sample revealed the highest content in free sugars, MUFA and tocopherols, while the wild mushroom revealed higher concentrations of SFA and PUFA, organic acids and phenolic compounds. The methanolic extract of the cultivated sample revealed the highest antioxidant potential and the highest antimicrobial activity with exception towards Gram (-) bacteria and A. ochraceus. Both extracts are considered safe since they did not show toxicity in liver primary cell culture. Ink cap 
mushroom soup is a known delicacy in several European countries and no toxicity has ever been reported.

This study provides new data concerning chemical characterization and bioactivity of Coprinus comatus (O.F.Müll.) Pers. Although with different profiles, cultivated and wild samples proved to be a good source of a wide range of nutrients and bioactive molecules.

\section{Acknowledgements}

The authors are grateful to Fundação para a Ciência e Tecnologia (FCT, Portugal) and COMPETE/QREN/EU for financial support to this work (research project PTDC/AGRALI/110062/2009 and BPD/4609/2008 to L. Barros) and to CIMO (strategic project PEst-OE/AGR/UI0690/2011). The authors also thank Serbian Ministry of Education and Science for financial support (grant number 173032).

\section{References}

Abreu, R.M.V., Ferreira, I.C.F.R., Calhelha, R.C., Lima, R.T., Vasconcelos, M.H., Adega, F., Chaves, R., Queiroz, M.J.R.P. (2011). Anti-hepatocellular carcinoma activity using humanHepG2 cells and hepatotoxicity of 6-substituted methyl 3aminothieno[3,2-b]pyridine-2-carboxylate derivatives: In vitro evaluation, cell cycle analysis and QSAR studies. Eur. J. Med. Chem. 46, 5800-5806.

Alves, M.J., Ferreira, I.C.F.R., Dias, J., Teixeira, V., Martins, A., Pintado, M. (2012). A review on antimicrobial activity of mushroom (Basidiomycetes) extracts and isolated compounds. Planta Med. 78, 1707-1718.

AOAC (1995). Official methods of analysis (16th Ed.). Arlington VA, USA: Association of Official Analytical Chemists. 
Bailey, C.J., Turner, S.L., Jakeman, K.J., Hayes, W.A. (1984). Effect of Coprinus comatus on plasma glucose concentrations in mice. Planta Med. 50, 525-526.

Barros, L., Pereira, C., Ferreira, I.C.F.R. (2013). Optimized analysis of organic acids in edible mushrooms from Portugal by ultra fast liquid chromatography and photodiode array detection. Food Anal. Method. 6, 309-316.

Booth, C. (1971). Fungal culture media. In J. R. Norris \& D. W. Ribbons (Eds.), Methods in microbiology (pp. 49-94). London and New York: Academic Press.

CLSI. Clinical and Laboratory Standards Institute. (2009). Methods for dilution antimicrobial susceptibility tests for bacteria that grow aerobically. Approved standard, 8th ed. CLSI publication M07-A8. Clinical and Laboratory Standards Institute, Wayne, PA.

Dijkstra, F.Y., Wikén, T.O. (1976). Studies on mushroom flavours 2. Flavour compounds in Coprinus comatus. Z Lebensm Unters Forsch 160, 263-269.

Ding, Z., Lu, Y., Lu, Z., Lv, F., Wang, Y., Bie, X., Wang, F., Zhang, K. (2010). Hypoglycaemic effect of comatin, an antidiabetic substance separated from Coprinus comatus broth, on alloxan-induced-diabetic rats. Food Chem. 121, 3943.

Ehssan, H.O. Moglad and. Saadabi, A.M. (2012). Screening of Antimicrobial Activity of Wild Mushrooms from Khartoum State of Sudan. Microbiol. J. 2, 64-69.

Espinel-Ingroff, A. (2001). Comparation of the E-test with the NCCLS M38-P method for antifungal susceptibility testing of common and emerging pathogenic filamentous fungi. J. Clin. Microbiol. 39, 1360-1367.

Ferreira, I.C.F.R., Barros, L., Abreu, R.M.V. (2009). Antioxidants in wild mushrooms. Curr. Med. Chem. 16, 1543-1560. 
Ferreira, I.C.F.R., Vaz, J.A., Vasconcelos, M.H., Martins, A. (2010). Compounds from wild mushrooms with antitumor potential. Anti-cancer Ag. Med. Chem. 10, 42436.

Grangeia, C., Heleno, S.A., Barros, L., Martins, A., Ferreira, I.C.F.R. (2011). Effects of trophism on nutritional and nutraceutical potential of wild edible mushrooms. Food Res. Int. 44, 1029-1035.

Heleno, S.A., Barros, L., Sousa, M.J., Martins, A., Ferreira, I.C.F.R. (2010). Tocopherols composition of Portuguese wild mushrooms with antioxidant capacity. Food Chem. 119, 1443-1450.

Jiang, X-G., Lian, M-X., Han, Y., Lv, S-M. (2013). Antitumor and immunomodulatory activity of a polysaccharide from fungus Coprinus comatus (Mull.:Fr.) Gray. Int. J. Biol. Macromol. DOI: 10.1016/j.ijbiomac.2013.04.033.

Kalač, P. (2009). Chemical composition and nutritional value of European species of wild growing mushrooms: A review. Food Chem. 113, 9-16.

Li, B., Lu, F., Suo, X., Nan, H., Li, B. (2010). Antioxidant Properties of Cap and Stipe from Coprinus comatus. Molecules 15, 1473-1486.

Reis, F.S., Barros, L., Martins, A., Ferreira, I.C.F.R. (2012a). Chemical composition and nutritional value of the most widely appreciated mushrooms: an inter-species comparative study. Food Chem. Toxicol. 50, 191-197.

Reis, F.S., Martins, A., Barros, L., Ferreira, I.C.F.R. (2012b). Antioxidant properties and phenolics profile of the most widely appreciated cultivated mushrooms: a comparative study between in vivo and in vitro samples. Food Chem. Toxicol. 50, 1201-1207.

Roupas, P., Keogh, J., Noakes, M., Margetts, C., Taylor, P. (2012). The role of edible mushrooms in health: evaluation of the evidence. J. Funct. Foods 4, 687-709. 
Tsai, H-L. (2007). Nonvolatile taste components of fruit bodies and mycelia of shaggy ink cap mushroom Coprinus comatus (O.F. Müll.: Fr.) Pers. (Agaricomycetideae). Int. J. Med. Mushrooms 9, 47-55.

Tsai, S-Y., Tsai, H-L., Mau, J-L. (2009). Antioxidant properties of Coprinus comatus. J. Food Biochem. 33, 368-389.

Tsukatani, T., Suenaga, H., Shiga, M., Noguchi, K., Ishiyama, M., Ezoe, T., Matsumoto, K. (2012). Comparison of the WST-8 colorimetric method and the CLSI broth microdilution method for susceptibility testing against drug-resistant bacteria. J. Microbiol. Method. 90, 160-166.

Vaz, J.A., Barros, L., Martins, A., Santos-Buelga, C., Vasconcelos, M.H., Ferreira, I.C.F.R. (2011). Chemical composition of wild edible mushrooms and antioxidant properties of their water soluble polysaccharidic and ethanolic fractions. Food Chem. 126, 610-616.

Yilmaz, N., Solmaz, M., Türkekul, I., Elmastaş, M. (2006). Fatty acid composition in some wild edible mushrooms growing in the middle Black Sea region of Turkey. Food Chem. 99, 168-174.

Yu, J., Cui, P-J., Zeng, W-L., Xie, X-L., Liang,W-J., Lin, G-B., Zeng, L. (2009). Protective effect of selenium-polysaccharides from the mycelia of Coprinus comatus on alloxan-induced oxidative stress in mice. Food Chem. 117, 42-47.

Zaidman, B-Z., Wasser, S. P., Nevo, E., Mahajna, J. (2008). Coprinus comatus and Ganoderma lucidum interfere with androgen receptor function in LNCaP prostate cancer cells. Mol. Biol. Rep. 35, 107-117. 
Table 1. Composition in nutrients expressed in dry weight basis (mean $\pm \mathrm{SD}$ ).

\begin{tabular}{|c|c|c|}
\hline & $\begin{array}{c}\text { Coprinus comatus } \\
\text { (Cultivated) }\end{array}$ & $\begin{array}{c}\text { Coprinus comatus } \\
\text { (Wild) }\end{array}$ \\
\hline Fat $(\mathrm{g} / 100 \mathrm{~g})$ & $1.98 \pm 0.00^{\mathrm{a}}$ & $1.80 \pm 0.10^{b}$ \\
\hline Proteins (g/100 g) & $10.98 \pm 0.32^{\mathrm{b}}$ & $11.84 \pm 0.25^{\mathrm{a}}$ \\
\hline Ash (g/100 g) & $10.46 \pm 0.17^{\mathrm{a}}$ & $10.07 \pm 0.57^{\mathrm{a}}$ \\
\hline Carbohydrates (g/100 g) & $76.57 \pm 0.26^{\mathrm{a}}$ & $76.29 \pm 0.41^{\mathrm{a}}$ \\
\hline Energy (kcal/100 g) & $368.08 \pm 0.47^{\mathrm{a}}$ & $368.72 \pm 1.27^{\mathrm{a}}$ \\
\hline Fructose $(\mathrm{g} / 100 \mathrm{~g})$ & $0.11 \pm 0.01$ & nd \\
\hline Mannitol (g/100 g) & $1.41 \pm 0.11^{\mathrm{b}}$ & $1.84 \pm 0.14^{\mathrm{a}}$ \\
\hline Trehalose (g/100 g) & $8.75 \pm 0.02^{\mathrm{a}}$ & $5.41 \pm 0.38^{\mathrm{b}}$ \\
\hline Total Sugars (g/100 g) & $10.27 \pm 0.12^{\mathrm{a}}$ & $7.25 \pm 0.52^{b}$ \\
\hline $\mathrm{C} 16: 0$ & $8.58 \pm 0.25^{b}$ & $12.88 \pm 0.11^{\mathrm{a}}$ \\
\hline C18:0 & $2.09 \pm 0.01^{\mathrm{b}}$ & $2.27 \pm 0.01^{\mathrm{a}}$ \\
\hline C18:1n9 & $36.38 \pm 0.17^{\mathrm{a}}$ & $13.46 \pm 0.06^{\mathrm{b}}$ \\
\hline $\mathrm{C} 18: 2 \mathrm{n} 6$ & $50.49 \pm 0.08^{b}$ & $64.08 \pm 0.07^{\mathrm{a}}$ \\
\hline SFA (relative percentage) & $11.82 \pm 0.24^{\mathrm{b}}$ & $18.72 \pm 0.13^{\mathrm{a}}$ \\
\hline MUFA (relative percentage) & $36.75 \pm 0.13^{\mathrm{a}}$ & $15.27 \pm 0.06^{\mathrm{b}}$ \\
\hline PUFA (relative percentage) & $51.43 \pm 0.11^{\mathrm{b}}$ & $66.01 \pm 0.06^{\mathrm{a}}$ \\
\hline$\alpha$-tocopherol $(\mu \mathrm{g} / 100 \mathrm{~g})$ & nd & $13.24 \pm 0.65$ \\
\hline$\beta$-tocopherol $(\mu \mathrm{g} / 100 \mathrm{~g})$ & $375.99 \pm 10.77$ & nd \\
\hline$\gamma$-tocopherol $(\mu \mathrm{g} / 100 \mathrm{~g})$ & $165.57 \pm 6.68$ & nd \\
\hline$\delta$-tocopherol $(\mu \mathrm{g} / 100 \mathrm{~g})$ & $46.67 \pm 3.55^{\mathrm{a}}$ & $31.76 \pm 1.99^{b}$ \\
\hline Total tocopherols $(\mu \mathrm{g} / 100 \mathrm{~g})$ & $588.24 \pm 7.64^{\mathrm{a}}$ & $45.01 \pm 2.64^{\mathrm{b}}$ \\
\hline
\end{tabular}

nd- not detected.

Main fatty acids: C16:0 (Palmitic acid), C18:0 (Stearic acid), C18:1n9 (Oleic acid) and C18:2n6 (Linoleic acid);20 more fatty acids were identified in trace amounts. SFASaturated fatty acids; MUFA- Monounsaturated fatty acids; PUFA- Polyunsaturated fatty acids.

In each line different letters mean significant differences $(p<0.05)$. 
Table 2. Composition in non-nutrients expressed in dry weight basis (mean $\pm \mathrm{SD}$ ).

\begin{tabular}{lcc}
\hline & $\begin{array}{c}\text { Coprinus comatus } \\
(\text { Cultivated })\end{array}$ & $\begin{array}{c}\text { Coprinus comatus } \\
(\text { Wild })\end{array}$ \\
\hline Oxalic acid $(\mathrm{g} / 100 \mathrm{~g})$ & $0.46 \pm 0.00^{\mathrm{b}}$ & $0.68 \pm 0.01^{\mathrm{a}}$ \\
Quinic acid $(\mathrm{g} / 100 \mathrm{~g})$ & $2.92 \pm 0.11^{\mathrm{b}}$ & $3.37 \pm 0.38^{\mathrm{a}}$ \\
Malic acid $(\mathrm{g} / 100 \mathrm{~g})$ & $2.77 \pm 0.13^{\mathrm{b}}$ & $4.08 \pm 0.22^{\mathrm{a}}$ \\
Citric acid $(\mathrm{g} / 100 \mathrm{~g})$ & $3.55 \pm 0.02^{\mathrm{b}}$ & $11.84 \pm 0.22^{\mathrm{a}}$ \\
Fumaric acid $(\mathrm{g} / 100 \mathrm{~g})$ & $0.27 \pm 0.00^{\mathrm{b}}$ & $0.65 \pm 0.02^{\mathrm{a}}$ \\
Total $(\mathrm{g} / 100 \mathrm{~g})$ & $9.97 \pm 0.00^{\mathrm{b}}$ & $20.63 \pm 0.39^{\mathrm{a}}$ \\
\hline Gallic acid $(\mathrm{mg} / 100 \mathrm{~g})$ & $0.10 \pm 0.00$ & $\mathrm{nd}$ \\
$p$-Hydroxybenzoic acid $(\mathrm{mg} / 100 \mathrm{~g})$ & $0.08 \pm 0.00^{\mathrm{b}}$ & $0.09 \pm 0.00^{\mathrm{a}}$ \\
$p$-Coumaric acid $(\mathrm{mg} / 100 \mathrm{~g})$ & $\mathrm{nd}$ & $0.15 \pm 0.00$ \\
Total $(\mathrm{mg} / 100 \mathrm{~g})$ & $0.17 \pm 0.00^{\mathrm{b}}$ & $0.24 \pm 0.00^{\mathrm{a}}$ \\
Cinnamic acid $(\mathrm{mg} / 100 \mathrm{~g})$ & $0.10 \pm 0.00^{\mathrm{a}}$ & $0.08 \pm 0.00^{\mathrm{b}}$ \\
\hline
\end{tabular}

nd- not detected.

In each line different letters mean significant differences $(p<0.05)$. 
Table 3. Antioxidant activity of the methanolic extracts (mean \pm SD).

\begin{tabular}{|c|c|c|c|}
\hline & Assay & $\begin{array}{l}\text { Coprinus comatus } \\
\text { (Cultivated) }\end{array}$ & $\begin{array}{c}\text { Coprinus comatus } \\
\text { (Wild) }\end{array}$ \\
\hline \multirow{2}{*}{ Reducing power } & $\begin{array}{l}\text { Folin-ciocalteu } \\
\text { (mg GAE/g extract) }\end{array}$ & $25.98 \pm 0.50^{\mathrm{a}}$ & $24.61 \pm 2.02^{\mathrm{a}}$ \\
\hline & $\begin{array}{l}\text { Ferricyanide/Prussian blue } \\
\left(\mathrm{EC}_{50} ; \mathrm{mg} / \mathrm{mL}\right)\end{array}$ & $1.05 \pm 0.01^{\mathrm{b}}$ & $1.64 \pm 0.02^{\mathrm{a}}$ \\
\hline Radical scavenging activity & $\begin{array}{l}\text { DPPH scavenging activity } \\
\left(\mathrm{EC}_{50} ; \mathrm{mg} / \mathrm{mL}\right)\end{array}$ & $5.11 \pm 0.18^{\mathrm{a}}$ & $3.76 \pm 0.48^{\mathrm{b}}$ \\
\hline \multirow{2}{*}{ Lipid peroxidation inhibition } & $\begin{array}{l}\beta \text {-carotene/linoleate } \\
\left(\mathrm{EC}_{50} ; \mathrm{mg} / \mathrm{mL}\right)\end{array}$ & $0.36 \pm 0.03^{b}$ & $1.88 \pm 0.84^{\mathrm{a}}$ \\
\hline & $\begin{array}{l}\text { TBARS } \\
\left(\mathrm{EC}_{50} ; \mathrm{mg} / \mathrm{mL}\right)\end{array}$ & $1.15 \pm 0.27^{b}$ & $1.59 \pm 0.23^{\mathrm{a}}$ \\
\hline
\end{tabular}

Concerning the Folin-Ciocalteu assay, higher values mean higher reducing power; for the other assays, the results are presented in $\mathrm{EC}_{50}$ values, what means that higher values correspond to lower reducing power or antioxidant potential. EC 50 $_{5}$ : Extract concentration corresponding to $50 \%$ of antioxidant activity or 0.5 of absorbance for the Ferricyanide/Prussian blue assay.

In each line different letters mean significant differences $(\mathrm{p}<0.05)$. 
Table 4. Antibacterial activity $(\mathrm{mg} / \mathrm{mL})$ of the methanolic extracts and standard drugs $($ mean $\pm \mathrm{SD})$.

\begin{tabular}{|c|c|c|c|c|c|}
\hline Bacteria & & $\begin{array}{c}\text { Coprinus comatus } \\
\text { (Cultivated) }\end{array}$ & $\begin{array}{l}\text { Coprinus comatus } \\
\text { (Wild) }\end{array}$ & Ampicillin & Streptomycin \\
\hline \multirow{2}{*}{ Staphylococcus aureus } & MIC & $0.0625 \pm 0.00^{c}$ & $1.5 \pm 0.10^{\mathrm{a}}$ & $0.25 \pm 0.05^{\mathrm{b}}$ & $0.04 \pm 0.00^{\mathrm{c}}$ \\
\hline & $\mathrm{MBC}$ & $0.125 \pm 0.00^{\mathrm{bc}}$ & $3.0 \pm 0.30^{\mathrm{a}}$ & $0.37 \pm 0.02^{\mathrm{b}}$ & $0.09 \pm 0.00^{\mathrm{c}}$ \\
\hline \multirow[b]{2}{*}{ Bacillus cereus } & MIC & $0.0625 \pm 0.00^{\mathrm{d}}$ & $0.75 \pm 0.00^{\mathrm{a}}$ & $0.25 \pm 0.00^{\mathrm{b}}$ & $0.09 \pm 0.00^{\mathrm{c}}$ \\
\hline & MBC & $0.125 \pm 0.01^{\mathrm{c}}$ & $3.0 \pm 0.10^{\mathrm{a}}$ & $0.37 \pm 0.02^{\mathrm{b}}$ & $0.17 \pm 0.01^{\mathrm{c}}$ \\
\hline \multirow{2}{*}{ Micrococcus flavus } & MIC & $1.5 \pm 0.10^{\mathrm{a}}$ & $1.5 \pm 0.30^{\mathrm{a}}$ & $0.25 \pm 0.03^{\mathrm{b}}$ & $0.17 \pm 0.020^{\mathrm{c}}$ \\
\hline & $\mathrm{MBC}$ & $3.0 \pm 0.30^{\mathrm{b}}$ & $6.25 \pm 0.30^{\mathrm{a}}$ & $0.37 \pm 0.00^{\mathrm{c}}$ & $0.34 \pm 0.02^{\mathrm{c}}$ \\
\hline \multirow{2}{*}{ Listeria monocytogenes } & MIC & $0.75 \pm 0.10^{\mathrm{b}}$ & $3.0 \pm 0.10^{\mathrm{a}}$ & $0.37 \pm 0.01^{\mathrm{c}}$ & $0.17 \pm 0.01^{\mathrm{d}}$ \\
\hline & $\mathrm{MBC}$ & $3.0 \pm 0.00^{\mathrm{b}}$ & $6.25 \pm 0.30^{\mathrm{a}}$ & $0.49 \pm 0.03^{\mathrm{c}}$ & $0.34 \pm 0.00^{\mathrm{c}}$ \\
\hline \multirow{2}{*}{ Pseudomonas aeruginosa } & MIC & $0.35 \pm 0.03^{\mathrm{c}}$ & $1.5 \pm 0.30^{\mathrm{a}}$ & $0.74 \pm 0.02^{\mathrm{b}}$ & $0.17 \pm 0.04^{\mathrm{d}}$ \\
\hline & $\mathrm{MBC}$ & $3.0 \pm 0.10^{\mathrm{a}}$ & $3.0 \pm 0.30^{\mathrm{a}}$ & $1.24 \pm 0.00^{\mathrm{b}}$ & $0.34 \pm 0.03^{\mathrm{c}}$ \\
\hline \multirow{2}{*}{ Salmonella typhimurium } & MIC & $3.0 \pm 0.30^{\mathrm{a}}$ & $1.5 \pm 0.00^{\mathrm{b}}$ & $0.37 \pm 0.01^{\mathrm{c}}$ & $0.17 \pm 0.00^{\mathrm{d}}$ \\
\hline & $\mathrm{MBC}$ & $6.25 \pm 0.10^{\mathrm{a}}$ & $3.0 \pm 0.00^{\mathrm{b}}$ & $0.49 \pm 0.03^{\mathrm{c}}$ & $0.34 \pm 0.01^{\mathrm{c}}$ \\
\hline \multirow{2}{*}{ Escherichia coli } & MIC & $3.0 \pm 0.10^{\mathrm{a}}$ & $3.0 \pm 0.10^{\mathrm{a}}$ & $0.25 \pm 0.05^{\mathrm{b}}$ & $0.17 \pm 0.03^{\mathrm{c}}$ \\
\hline & $\mathrm{MBC}$ & $6.25 \pm 0.00^{\mathrm{a}}$ & $6.25 \pm 0.30^{\mathrm{a}}$ & $0.49 \pm 0.05^{\mathrm{b}}$ & $0.34 \pm 0.02^{\mathrm{b}}$ \\
\hline \multirow{2}{*}{ Enterobacter cloacae } & MIC & $3.0 \pm 0.10^{\mathrm{a}}$ & $1.5 \pm 0.10^{\mathrm{b}}$ & $0.37 \pm 0.05^{\mathrm{c}}$ & $0.26 \pm 0.01^{\mathrm{c}}$ \\
\hline & MBC & $6.25 \pm 0.10^{\mathrm{a}}$ & $6.25 \pm 0.00^{\mathrm{a}}$ & $0.74 \pm 0.07^{\mathrm{b}}$ & $0.52 \pm 0.02^{\mathrm{b}}$ \\
\hline
\end{tabular}

MIC- minimum inhibitory concentration; MBC- minimum bactericidal concentration. In each line different letters mean significant differences $(p<0.05)$. 
Table 5. Antifungal activity $(\mathrm{mg} / \mathrm{mL})$ of the methanolic extracts and standard drugs $($ mean $\pm \mathrm{SD})$.

\begin{tabular}{llcccc}
\hline Fungi & Coprinus & $\begin{array}{c}\text { Coprinus } \\
\text { comatus } \\
\text { (Cultivated) }\end{array}$ & $\begin{array}{c}\text { comatus } \\
\text { (Wild) }\end{array}$ & Bifonazole & Ketoconazole \\
\hline Aspergillus fumigatus & MIC & $3.0 \pm 0.00^{\mathrm{a}}$ & $3.0 \pm 0.00^{\mathrm{a}}$ & $0.15 \pm 0.03^{\mathrm{b}}$ & $0.20 \pm 0.00^{\mathrm{b}}$ \\
& MFC & $6.25 \pm 0.10^{\mathrm{a}}$ & $6.25 \pm 0.10^{\mathrm{a}}$ & $0.20 \pm 0.03^{\mathrm{b}}$ & $0.50 \pm 0.10^{\mathrm{b}}$ \\
Aspergillus versicolor & MIC & $0.20 \pm 0.06^{\mathrm{b}}$ & $0.75 \pm 0.03^{\mathrm{a}}$ & $0.10 \pm 0.06^{\mathrm{c}}$ & $0.20 \pm 0.06^{\mathrm{b}}$ \\
& MFC & $3.0 \pm 0.00^{\mathrm{a}}$ & $1.5 \pm 0.00^{\mathrm{b}}$ & $0.20 \pm 0.06^{\mathrm{c}}$ & $0.50 \pm 0.06^{\mathrm{c}}$ \\
Aspergillus ochraceus & MIC & $1.5 \pm 0.30^{\mathrm{a}}$ & $0.75 \pm 0.03^{\mathrm{b}}$ & $0.15 \pm 0.03^{\mathrm{c}}$ & $1.50 \pm 0.00^{\mathrm{a}}$ \\
& MFC & $3.0 \pm 0.30^{\mathrm{a}}$ & $3.0 \pm 0.30^{\mathrm{a}}$ & $0.20 \pm 0.00^{\mathrm{c}}$ & $2.0 \pm 0.30^{\mathrm{b}}$ \\
Aspergillus niger & MIC & $1.5 \pm 0.10^{\mathrm{b}}$ & $3.0 \pm 0.00^{\mathrm{a}}$ & $0.15 \pm 0.03^{\mathrm{c}}$ & $0.20 \pm 0.03^{\mathrm{c}}$ \\
& MFC & $3.0 \pm 0.00^{\mathrm{b}}$ & $12.5 \pm 0.90^{\mathrm{a}}$ & $0.20 \pm 0.06^{\mathrm{c}}$ & $0.50 \pm 0.03^{\mathrm{c}}$ \\
Trichoderma viride & MIC & $0.2 \pm 0.06^{\mathrm{c}}$ & $1.5 \pm 0.00^{\mathrm{a}}$ & $0.15 \pm 0.03^{\mathrm{c}}$ & $1.0 \pm 0.00^{\mathrm{b}}$ \\
Penicillium funiculosum & MFC & $1.5 \pm 0.10^{\mathrm{b}}$ & $3.0 \pm 0.00^{\mathrm{a}}$ & $0.20 \pm 0.00^{\mathrm{c}}$ & $1.0 \pm 0.30^{\mathrm{bc}}$ \\
& MIC & $0.20 \pm 0.06^{\mathrm{b}}$ & $1.5 \pm 0.10^{\mathrm{a}}$ & $0.20 \pm 0.06^{\mathrm{b}}$ & $0.20 \pm 0.03^{\mathrm{b}}$ \\
Penicillium ochrochloron & MFC & $3.0 \pm 0.30^{\mathrm{a}}$ & $3.0 \pm 0.30^{\mathrm{a}}$ & $0.25 \pm 0.03^{\mathrm{c}}$ & $0.50 \pm 0.00^{\mathrm{d}}$ \\
Penicillium verrucosum & MIC & $0.20 \pm 0.00^{\mathrm{c}}$ & $0.75 \pm 0.10^{\mathrm{b}}$ & $0.20 \pm 0.06^{\mathrm{c}}$ & $2.5 \pm 0.30^{\mathrm{a}}$ \\
var. cyclopium & MFC & $3.0 \pm 0.10^{\mathrm{a}}$ & $1.5 \pm 0.10^{\mathrm{b}}$ & $0.25 \pm 0.03^{\mathrm{c}}$ & $3.5 \pm 0.10^{\mathrm{a}}$ \\
& MIC & $3.0 \pm 0.10^{\mathrm{a}}$ & $3.0 \pm 0.30^{\mathrm{a}}$ & $0.10 \pm 0.00^{\mathrm{b}}$ & $0.20 \pm 0.00^{\mathrm{b}}$ \\
& MFC & $6.25 \pm 0.00^{\mathrm{a}}$ & $6.25 \pm 0.00^{\mathrm{a}}$ & $0.20 \pm 0.00^{\mathrm{b}}$ & $0.30 \pm 0.00^{\mathrm{b}}$ \\
\hline
\end{tabular}

MIC- minimum inhibitory concentration; MFC- minimum fungicidal concentration. In each line different letters mean significant differences $(p<0.05)$. 
Table 6. Toxicity of the methanolic extracts and standard drug (mean \pm SD).

\begin{tabular}{lccc}
\hline & $\begin{array}{c}\text { Coprinus comatus } \\
\text { (Cultivated) }\end{array}$ & $\begin{array}{c}\text { Coprinus comatus } \\
\text { (Wild) }\end{array}$ & Ellipticine \\
\hline PLP2 $\left(\mathrm{GI}_{50}, \mu \mathrm{g} / \mathrm{mL}\right)$ & $>400$ & $>400$ & $2.06 \pm 0.03$ \\
\hline
\end{tabular}

$\mathrm{GI}_{50}$ values correspond to the extract/compound concentration achieving $50 \%$ of growth inhibition in liver primary culture PLP2. 


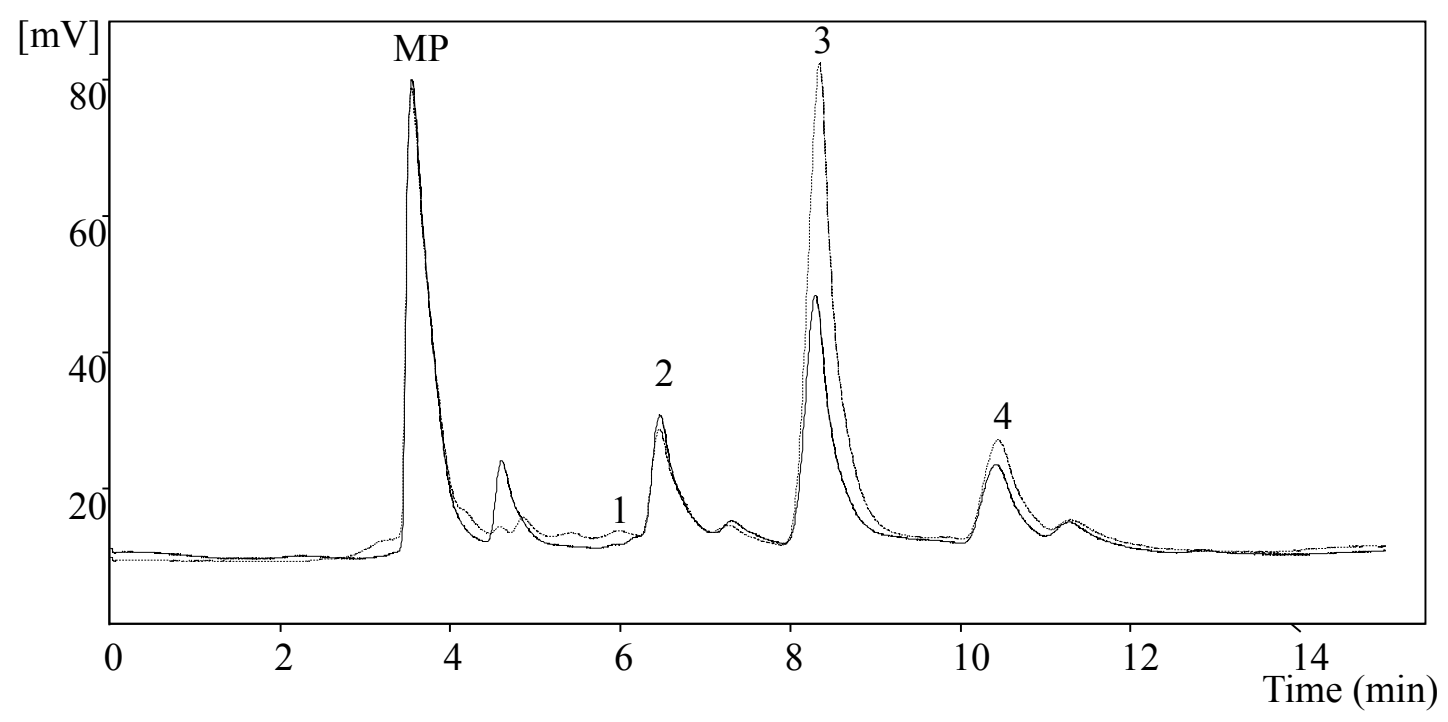

1A

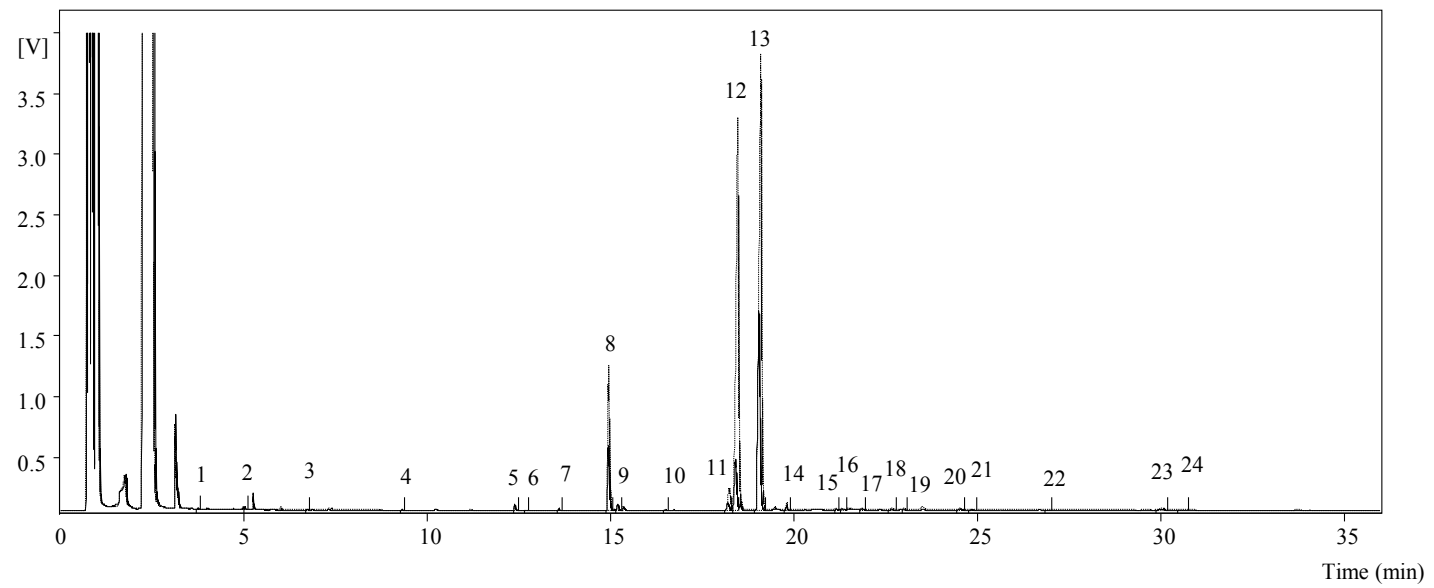

1B

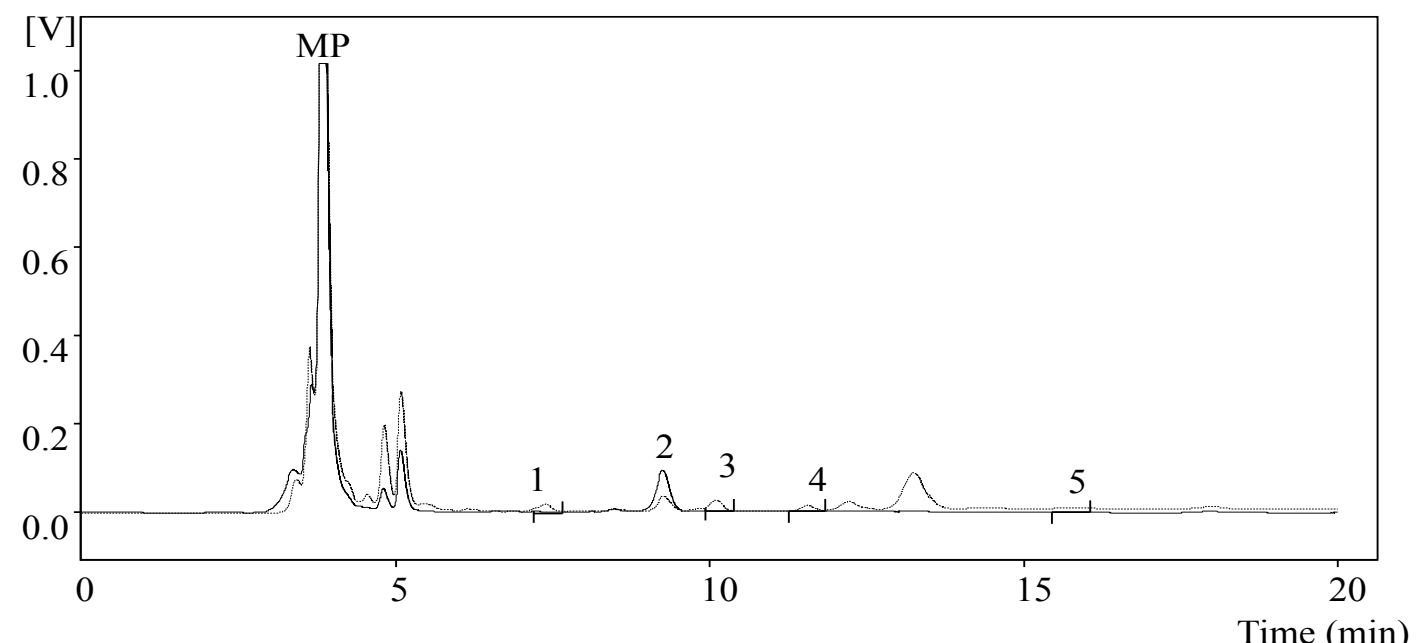

1C 
Figure 1. Nutrients individual chromatograms of cultivated (----) and wild ( - ) samples. 1A. Free sugars. 1- fructose, 2-mannitol, 3-trehalose, 4-raffinose (IS); 1B. Fatty acids. 1- Caproic acid (C6:0); 2-Caprylic acid (C8:0); 3-Capric acid (C10:0); 4Lauric acid (C12:0); 5-Myristic acid (C14:0); 6-Myristoleic acid (C14:1); 7 Pentadecanoic acid (C15:0); 8-Palmitic acid (C16:0); 9-Palmitoleic acid (C16:1); 10Heptadecanoic acid (C17:0);11-Stearic acid (C18:0); 12-Oleic acid (C18:1n9); 13Linoleic acid (C18:2n6c); 14-Linolenic acid (C18:3n3); 15-Arachidic acid (C20:0); 16cis-11-Eicosenoic acid (C20:1); 17-cis-11,14-Eicosadienoic acid (C20:2); 18-cis-11,14,17Eicosatrienoic acid and Heneicosanoic acid (C20:3n3+C21:0); 19-cis-5,8,11,14,17Eicosapentaenoic acid (C20:5n3);20-Behenic acid (C22:0); 21-Erucic acid (C22:1n9); 22Tricosanoic acid (C23:0); 23-Lignoceric acid (C24:0); 24-Nervonic acid (C24:1).1C. Tocopherols. 1 - $\alpha$-tocopherol, 2 - $\beta$-tocopherol, $\gamma$-tocopherol, $\delta$-tocopherol. MP-mobile phase 


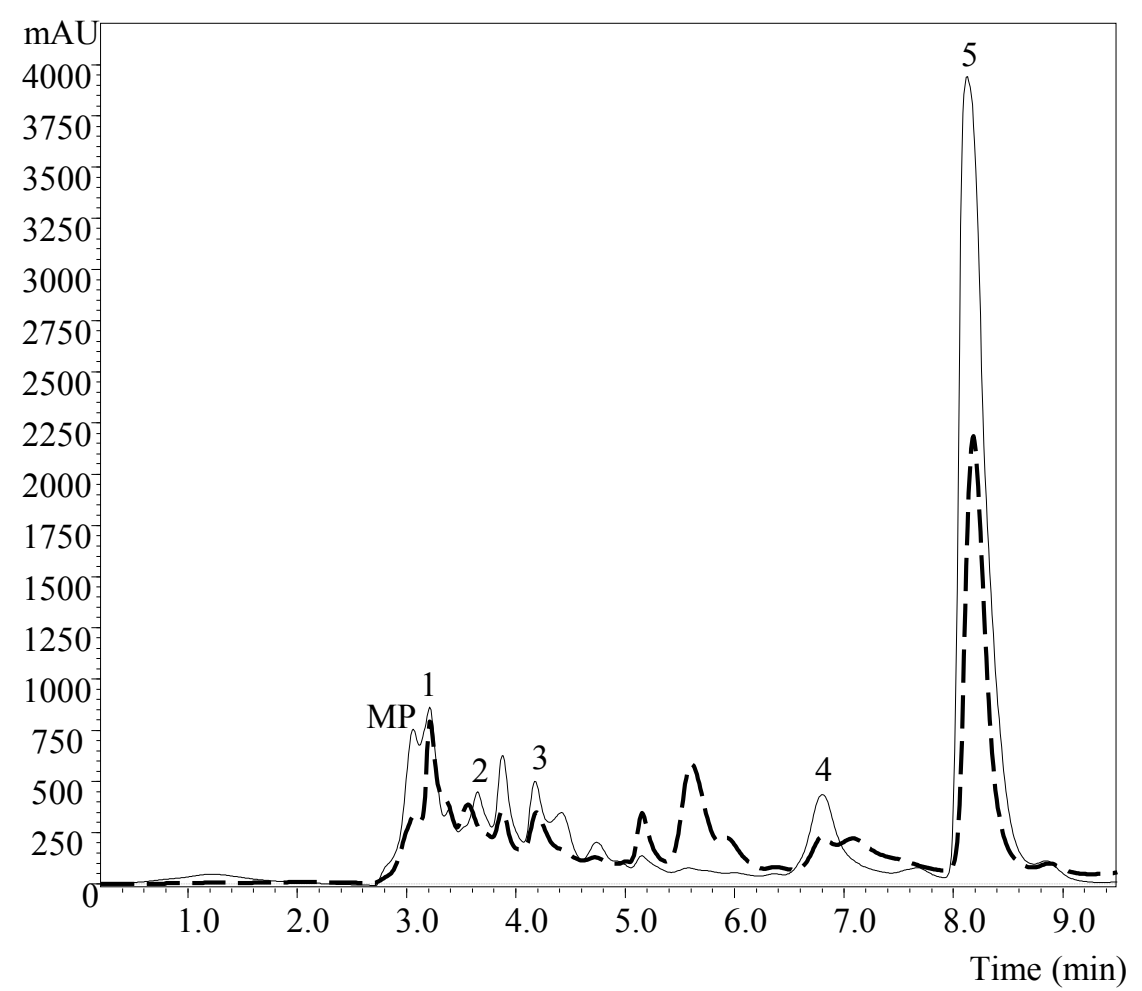

2A

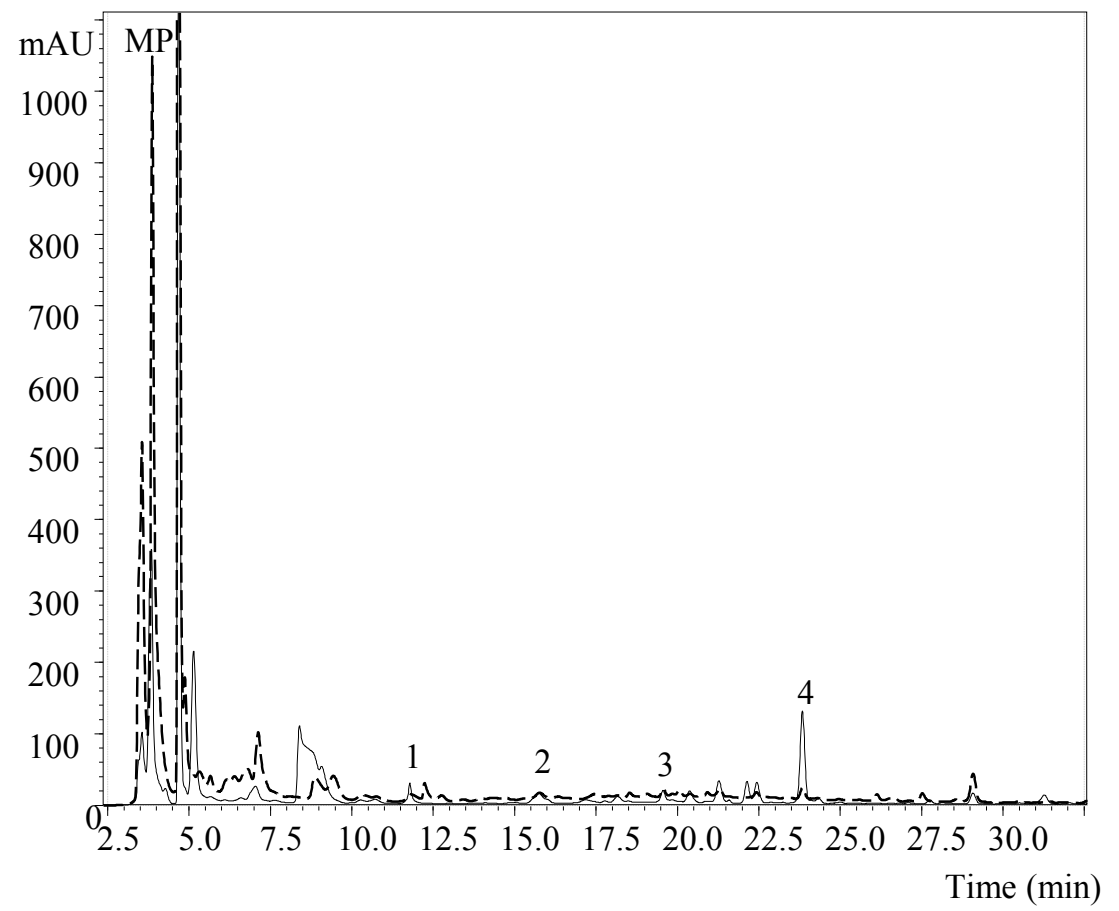

2B

Figure 2. Non-nutrients individual chromatograms of cultivated (----) and wild (-) samples. 2A. Organic acids. 1- oxalic acid; 2- quinic acid, 3- malic acid, 4- citric acid and 5- fumaric acid; 2B. Phenolic compounds. 1- Gallic acid; 2- $p$-Hydroxybenzoic acid; 3-p-Coumaric acid; 4-Cinnamic acid. MP- mobile phase. 